\title{
Studies on the Effect of Thyroid Hormone and Epidermal Growth Factor on the Cultured Human Cytotrophoblast
}

\author{
Hiroshi NISHII, Yoshiniko ASHITAKA, Motoyoshi MARUO AND \\ MATSUTO MOCHIZUKI \\ Department of Obstetrics and Gynecology, Kobe University School \\ of Medicine, Kobe 650, Japan
}

\begin{abstract}
We have previously reported that human placental cytotrophoblasts (C-cells) contain nuclear 3,5,3'-triiodo-L-thyronine $\left(\mathrm{T}_{3}\right)$ receptors. Using a C-cell culture system, the present study was undertaken to clarify some of the effects of $\mathrm{T}_{3}$ and EGF on trophoblastic cells. C-cells were purified from human term placenta by treatment with trypsin-DNAse and percoll gradient centrifugation aggregated, then fused, differentiating into multinuclear syncytiotrophoblasts (S-cells) with incubation times up to 96 $\mathrm{h}$ in vitro. As the incubation time increased, the number of immunocytochemically reactive cells with antibodies to hCG- $\alpha$, hCG- $\beta$ and hPL increased. Anti-EGF antibody reacted only with the initial C-cells, while anti-EGF receptor antibody reacted only with fused S-cells. Maximum secretion of hCG and hCG- $\alpha$ by the cultured cells was evident only when the cells were cultured in $\mathrm{T}_{3}\left(10^{-8} \mathrm{M}\right)$ or EGF $(10$ $\mathrm{ng} / \mathrm{ml}$ ) containing medium. When the initial cells were exposed to $10^{-8} \mathrm{M} \mathrm{T}_{3}$ from 0 to $48 \mathrm{~h}$ of incubation, the secretion in 48-96 h was significantly accelerated. However, exposure from 48 to $96 \mathrm{~h}$ had no effect on peptide excretion. Although an exposure of these cells to $10 \mathrm{ng} / \mathrm{ml} \mathrm{EGF}$ during $48-96 \mathrm{~h}$ of incubation stimulated the secretion of hCG and hCG- $\alpha, 0-48 \mathrm{~h}$ exposure did not produce any positive effect regardless of incubation time. These results indicated that the main target cell of $\mathrm{T}_{3}$ is the C-cell, while that of EGF is the S-cell. Furthermore, it is suggested that the interaction between $\mathrm{T}_{3}$ and its receptor facilitated functional cell differentiation. It is possible to propose a paracrine/autocrine control mechanism in which EGF synthesized by C-cells acts on S-cells.
\end{abstract}

Key words: EGF, EGF receptor, $\mathrm{T}_{3}$, Cell culture, Cytotrophoblast syncytiotrophoblast, Immunocytochemistry.

(Endocrinol Japon 38 : 279-286, 1991)

THE HUMAN villous trophoblast is composed of the cytotrophoblast (C-cell) and the syncytiotrophoblast (S-cell). C-cells, which have a proliferative character, fuse and differentiate into multinucleated S-cells [1-3]. The non-proliferative Scell possesses essential functions such as production and secretion of steroid and protein hormones for the maintenance of pregnancy [4-6]. Although the control mechanism in the trophoblast has not yet been elucidated, there have been reports that differentiation and proliferation in some mammalian cells are induced by a mechan-

Received: January 12, 1991

Accepted: April 19, 1991

Correspondence to: Dr. Yoshihiko ASHITAKA, Department of Obstetrics and Gynecology, Kobe University School of Medicine, Kusunoki-cho, Chuo-ku, Kobe 650, Japan. ism of receptor-mediated endocytosis of epidermal growth factor (EGF) [7], which is capable of stimulating hCG secretion by cultured human choriocarcinoma cells [8] and perifused human placenta [9]. The cell membrane of the human S-cell is rich in receptors for a number of growth factors including those for EGF [7], insulin [10], and the family of insulin-like growth factors (IGFs): IGF-I and IGF-II [11, 12], and somatomedin $\mathrm{A}$ and $\mathrm{C}[13,14]$.

In previous studies, we demonstrated that human placental trophoblasts contain nuclear 3, 5, 3' triiodo-L-thyronine $\left(\mathrm{T}_{3}\right)$ binding sites biochemically similar to those isolated from rat liver [15], and that these binding sites are mainly localized in the nuclei of C-cells [16]. Furthermore, in our culture system for trophoblastic cells the initially harvested 
C-cells changed morphologically and functionally into S-cells as the incubation time increased up to $120 \mathrm{~h}$ [16].

EGF stimulates hCG secretion in trophoblast $[17,18]$. Human placenta and isolated trophoblast cells are rich in EGF receptor [19]. It is suggested that EGF should perform possible physiological roles in feto-placental development. From the viewpoint of the mechanism of action of growth factors, the present study was undertaken to elucidate any differences in action between $\mathrm{T}_{3}$ and EGF, focusing on human term placental trophoblasts which morphologically and functionally change as incubation time increases.

\section{Materials and Methods}

\section{Chemicals and buffers}

3, 5, 3'-Triiodo-L-thyronine $\left(\mathrm{T}_{3}\right)$, trypsin and fetal calf serum (FCS) came from Sigma Chemical Co. (U.S.A.). Human EGF (homogeneous grade) was purchased from GiBCO Lab., Inc. (U.S.A.). These and the other chemicals used were of analytical grade.

\section{Isolation and cutlure of cytotrophoblast}

Human cytotrophoblast was isolated from human term placenta, as described previously [16] by a method which was originated by Kliman et al. [2] with slight modification. In short, freshly obtained placental trophoblasts digested with $0.125 \%$ trypsin and $0.4 \mathrm{mg} / \mathrm{m} l$ DNAse $\mathrm{I}$ in $\mathrm{Mg}^{++}$and $\mathrm{Ca}^{++}$ free Hunk's solution (Handai Biken, Osaka) at $37^{\circ} \mathrm{C}$ for $30 \mathrm{~min}$ was pelleted and further purified by Percoll gradient centrifugation. The mononuclear cells with a density of about $1.031 \mathrm{~g} / \mathrm{ml}$ were harvested and were adjusted to a concentration of $5 \times 10^{5}$ cells $/ \mathrm{m} l$. This was done by adding DMEM-H-G (Dulbeco's MEM containing $50 \mathrm{mM}$ glucose and $50 \mathrm{mM}$ HEPES, Handai Biken) supplemented with $50 \mu \mathrm{g} / \mathrm{ml}$ Tobramycin and $10 \%$ FCS. The harvested cells were then plated into Lab-Tek tissue culture 8 chambered-slides (Nunc, Inc., U.S.A.). The culture chambers were incubated with or without $\mathrm{T}_{3}$ or $\mathrm{EGF}$ in a humidified $5 \% \mathrm{CO}_{2}-95 \%$ air atmosphere at $37^{\circ} \mathrm{C}$ for 96 h. Every $24 \mathrm{~h}$ of incubation, the culture medium was withdrawn by gentle aspiration and frozen at $-40^{\circ} \mathrm{C}$ for later assays of human chorionic gonadotropin (hCG) and hCG- $\alpha$ subunit, and then recharged with fresh medium. At designated times the chambers and gaskets were removed, and the slide was washed with $10 \mathrm{mM}$ potassium phosphate buffer, $\mathrm{pH} 7.5$, containing $0.15 \mathrm{M} \mathrm{NaCl}$ (buffer A), and fixed with Bouin's solution for 15 min. Following fixation, the slides were washed with buffer $\mathrm{A}$ at room temperature. Later, these were immersed in buffer $\mathrm{A}$ at $4^{\circ} \mathrm{C}$ for up to 4 days, for further cytological and immunocytochemical studies. Cell viability on day 5, as assessed by trypan blue dye exclusion, was 95\%. hCG and hCG- $\alpha$ concentrations secreted into the media were determined by an enzyme immunoassay (Elmotec hCG, Mochida Pharmaceutical Co.), and by a radioimmunoassay [20], respectively. Crossreactivity of the anti-hCG- $\alpha$ to hCG was $0.2 \%$, and that of the anti-hCG to hCG- $\alpha$ was negligible. Therefore, hCG values interfering with the hCG- $\alpha$ RIA were ignored in the calculation of hCG- $\alpha$.

Immunocytochemical staining of the cultured cells

The Biotin-Streptavidin A Amplified System Kit (Biogenex Lab., U.S.A.) was used according to the biotin-streptavidin-peroxidase complex method. Mouse anti-human EGF monoclonal antibody and mouse anti-EGF receptor monoclonal antibody (Transformation Research, Inc., U.S.A.) were used as the primary antibodies, and both diluted at 1:1,000. The Percoll-purified mononuclear cells and the cultured cells attached to the slides were stained with hematoxylin and eosin. The residual cells were prepared for immunocytochemical staining. Non-specific immunoglobulin binding sites were blocked by $30 \mathrm{~min}$ preincubation with $5 \%$ goat serum. Non-immune rabbit serum as the control was applied for $60 \mathrm{~min}$. Biotin-linked mouse immunoglobulin was used for the second antibody.

\section{Results}

As shown in Fig. 1, in our culture system the initially harvested mononuclear cells began to fuse together and only $20 \%$ of the mononuclear cells which had adhered to the bottom of the culture chamber remained single at $24 \mathrm{~h}$ of incubation. Subsequently, the total number of mononuclear cells gradually decreased and about $3 \%$ remained unchanged at $96 \mathrm{~h}$. Fused cells increased to $15 \%$ of the total number of cells at $24 \mathrm{~h}, 42 \%$ at $48 \mathrm{~h}, 70 \%$ 


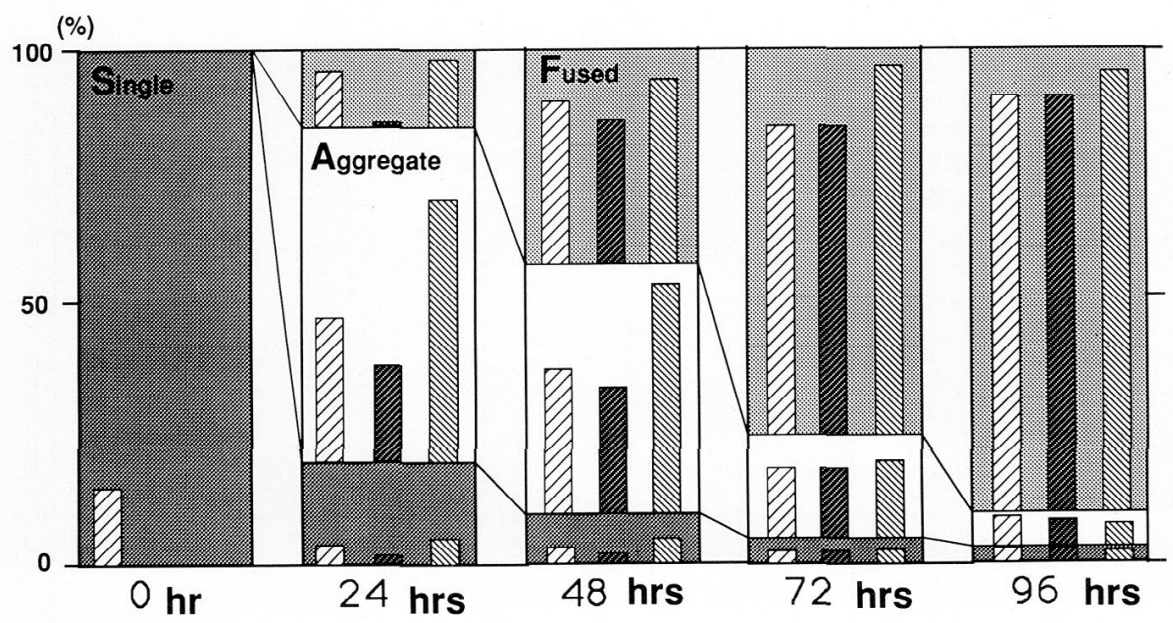

Fig. 1. Morphological changes in the cultured cells with the lapse of incubation time. Wide columns of single ( ), aggregate-type ( $\square$ ) and fused cells ( ) ) represent population ratios in the total number of cells. Narrow columns denote ratios of immunoreactive cells for hCG- $\alpha$ ( $\mathbb{Z}$ ), hCG- $\beta$ ( wide columns.
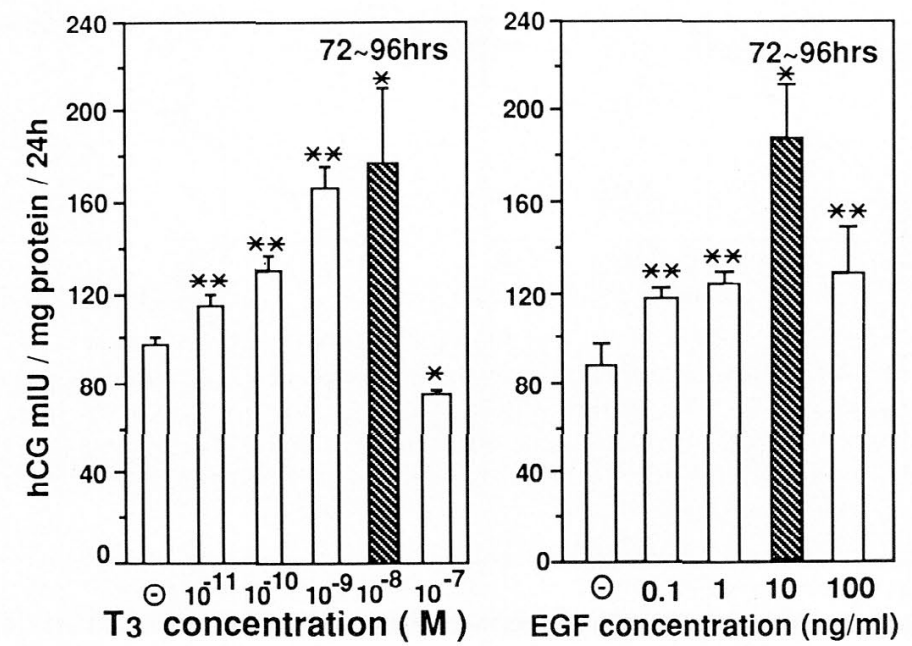

Fig. 2. Effect of $T_{3}$ and EGF on hCG secretion by cultured cells. The harvested mononucleated cells were incubated for $96 \mathrm{~h}$ in the presence of various concentrations of $\mathrm{T}_{3}$ or EGF. Every $24 \mathrm{~h}$ the medium was changed to a fresh one, and at $96 \mathrm{~h}$ of incubation the hCG concentration in the medium was assayed by an enzyme immunoassay as described in "Materials and Methods". Each bar represents the mean \pm SD for 6 replicates. Data were compared by the paired $t$ test.

$* \mathrm{p}<0.01$ vs control. ** $\mathrm{p}<0.05$ vs control.

at $72 \mathrm{~h}$ and $90 \%$ at $96 \mathrm{~h}$, similar to the results obtained by Kliman et al. [2]. Immunoreactive hCG- $\alpha$ was found in $15 \%$ of the initially harvested mononuclear cells, while neither hPL nor hCG- $\beta$ was recognized in these cells. At $48 \mathrm{~h}$ and thereafter, the ratio of the cells, aggregate or fused, which reacted immunocytochemically with anti-hCG- $\alpha$ and anti-hCG- $\beta$ was relatively similar, reaching $\geqq 90 \%$ at 96 h of incubation. On the other hand, immunoreactive hPL was already recognized in $30 \%$ of the single and $90 \%$ of the aggregate-typed cells at $24 \mathrm{~h}$ of incubation. 
(a)

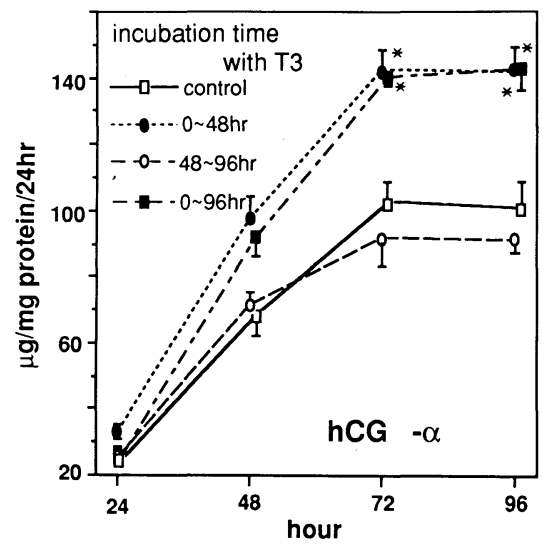

(b)

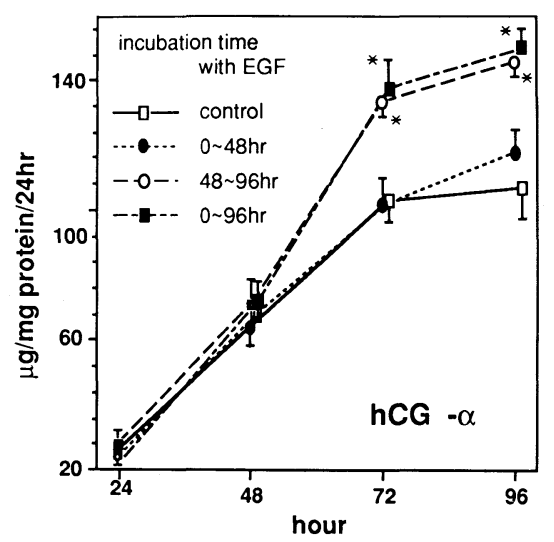

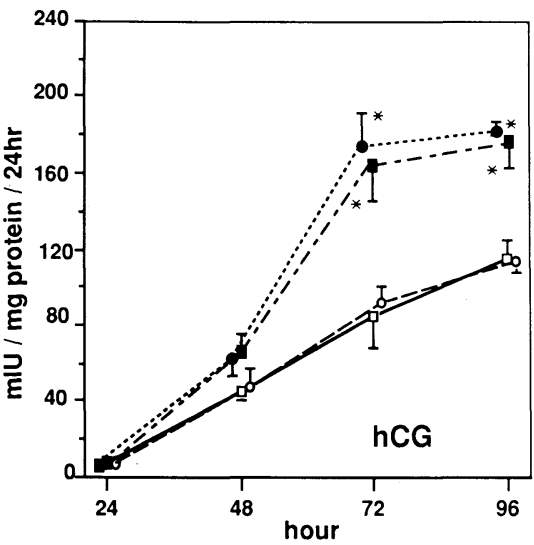

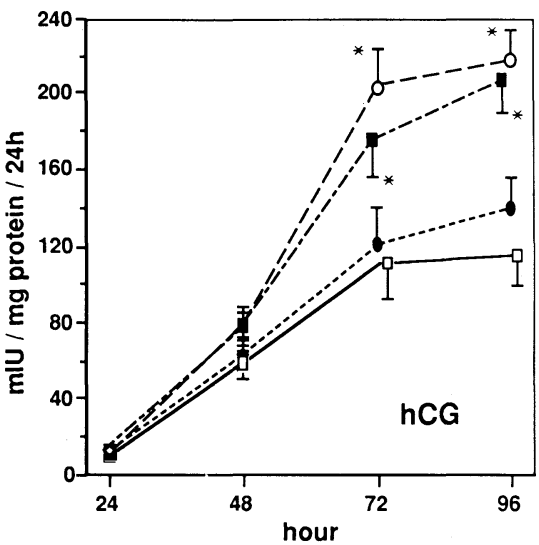

Fig. 3. Time course effect of $T_{3}$ and EGF on cultured cells. (a) Addition of $T_{3}$ to the media for the first $48 \mathrm{~h}$ had nearly the same effect on hCG and hCG- $\alpha$ secretion as the entired 96-h incubation with $\mathrm{T}_{3}$. (b) The addition of EGF $(10 \mathrm{ng} / \mathrm{ml})$ for the latter $48 \mathrm{~h}$ had nearly the same effect on hCG and hCG- $\alpha$ secretion as the entire 96-h incubation with EGF. Each bar represents the mean \pm SD for 6 replicates. $* \mathrm{p}<0.01$ vs control.

As shown in Fig. 2, the rate of secretion of hCG into the media by the cultured cells between 72 and $96 \mathrm{~h}$ of incubation was dose-dependently stimulated by $10^{-10}-10^{-8} \mathrm{M} \mathrm{T}_{3}$. However, a higher concentration $\left(10^{-7} \mathrm{M}\right) \mathrm{T}_{3}$ suppressed hCG secretion as compared to the control level $(\mathrm{p}<$ $0.01)$. EGF $(0.1-100 \mathrm{ng} / \mathrm{m} l)$ also stimulated hCG secretion (at least $\mathrm{p}<0.05$ ). The maximum stimulation was observed at $10^{-8} \mathrm{M} \mathrm{T}_{3}$ or $10 \mathrm{ng} / \mathrm{ml}$ EGF ( $p<0.01$, respectively). Any concentration of $\mathrm{T}_{3}$ or EGF used in the present study induced an increase in neither the total number of nuclei nor DNA content, and no further morphological changes in the cultured cells were seen (data not shown).

Next, the initially harvested C-cells were treated with $10^{-8} \mathrm{M} \mathrm{T}_{3}$ or $10 \mathrm{ng} / \mathrm{ml} \mathrm{EGF}$ for the first half
( 0 to $48 \mathrm{~h}$ ) or the latter half ( 48 to $96 \mathrm{~h}$ ) of the incubation time. The addition of $\mathrm{T}_{3}$ to media for the first $48 \mathrm{~h}$ had nearly the same effect on hCG and hCG- $\alpha$ secretion as that by treatment with $\mathrm{T}_{3}$ for the whole $96 \mathrm{~h}$. During the latter half of incubation, exposure to $T_{3}$, however, did not increase the secretion rates of hCG and hCG- $\alpha$ to the control level (Fig. 3-a). On the other hand, EGF at the optimal concentration added to the medium from the start and maintained throughout, or between 48 to $96 \mathrm{~h}$ incubation, increased both hCG and hCG- $\alpha$ secretion rates at and after $72 \mathrm{~h}$ of incubation. Secretion rates of these proteins were not stimulated when the cultured cells were exposed to EGF for only the first $48 \mathrm{~h}$ (Fig. 3-b).

The initially harvested C-cells were positively 


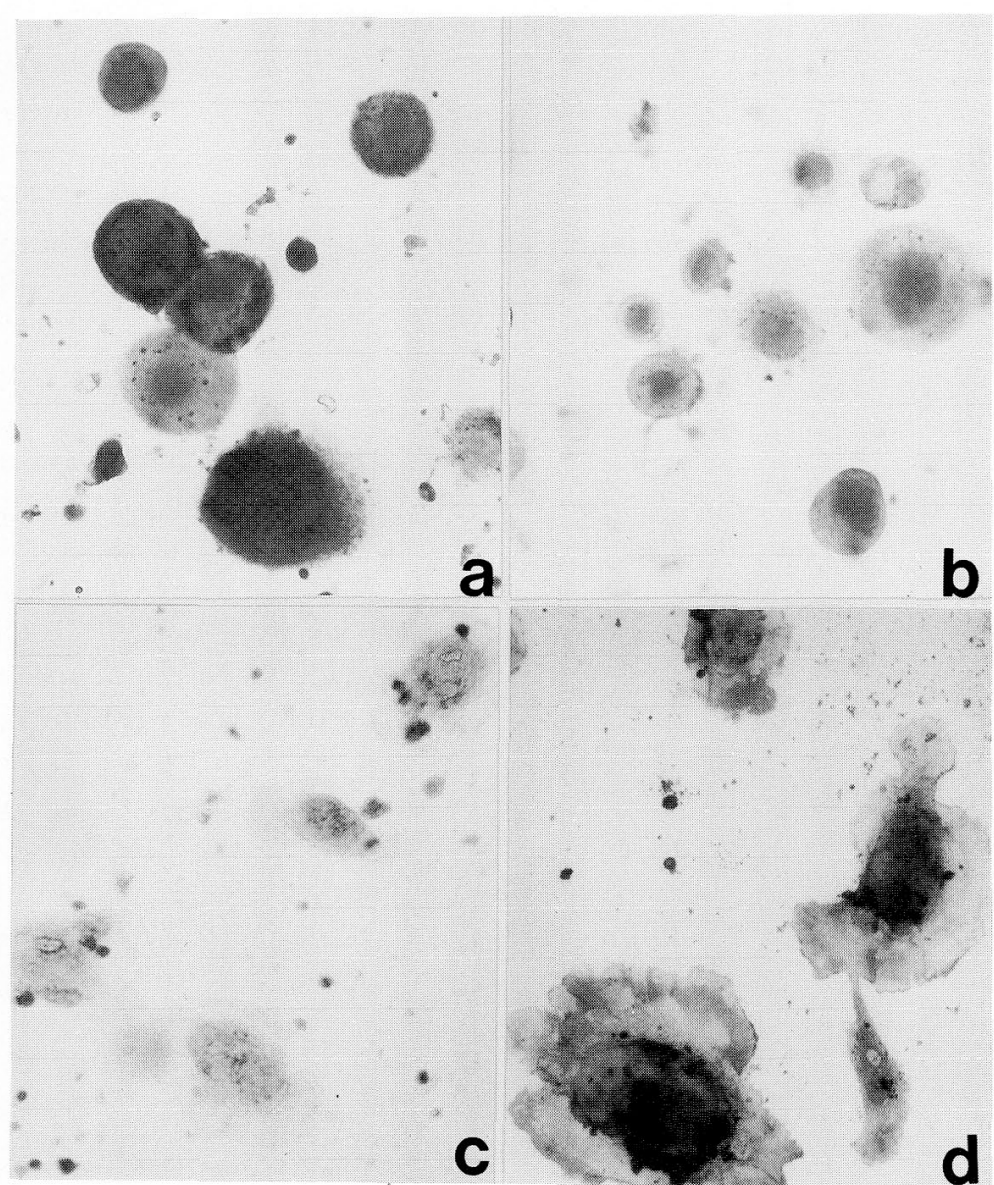

Fig. 4. Immunocytostaining with anti-EGF and anti-EGF receptor antibody (original magnification: $\times 400$ ). The initially harvested C-cells $(\mathrm{a}$ and $\mathrm{b}$ ) and the multinuclear fused cells cultured for $72 \mathrm{~h} \mathrm{(c}$ and d) were immunocytochemically stained for EGF (a and c) and EGF receptor (b and d), as described in "Materials and Methods".

stained and the multinucleated S-cells cultured for $72 \mathrm{~h}$ were negatively stained with anti-EGF antibody. On the other hand, anti-EGF receptor antibody reacted positively with S-cells and negatively with C-cells (Fig. 4).

\section{Discussion}

As discussed in the previous paper [16] and also in the present study, initially harvested mononuclear cells morphologically resembled C-cells in light microscopy. These cells aggregated and transformed into multinuclear cells during up to $96 \mathrm{~h}$ of incubation. More than $80 \%$ of the fused cells, especially at and after $72 \mathrm{~h}$ of incubation, developed the ability to synthesize hCG- $\alpha$, hCG- $\beta$ and hPL. These results indicated that mononuc- lear C-cells differentiated into multinuclear S-cells via aggregated intermediate-type cells. It is of interest that not only a greater part of the aggregated cells but also mononuclear cells (although the number of these decreased drastically following incubation) also reacted with antibodies to these peptides. It has been reported that cells of a morphology intermediate between that of C- and S-cells have been found [1, 3]. Fifteen percent of the initial mononuclear cells reacted only with anti-hCG- $\alpha$, suggesting that, strictly speaking, these cells might belong to the intermediate-type. The current definition of cultured C-cells as distinguished from S-cells is vague. It is generally admitted that the initially harvested or cultured mononuclear single cell is a C-cell [2, $18,21]$. However, even though there were remaining unaggregated mononuclear cells which 
reacted immunocytochemically with antibodies to hCG- $\alpha$, hCG- $\beta$ and hPL, these cells should not be regarded as C-cells, because the C-cell of the normal placenta is described as rich in free ribosome but possessing very little endoplasmic reticulum where these hormones are synthesized [22]. These cells should perhaps be more critically defined on the basis of their respective functions and also electron-microscopic findings.

In the culture system used in the present study, the addition of $\mathrm{T}_{3}$ to the medium at the start of incubation facilitated hCG and hCG- $\alpha$ secretion after a lag period of $48 \mathrm{~h}$. A similar effect was reproduced by $T_{3}$ added in the first $48 \mathrm{~h}$ of culture, while exposure to $T_{3}$ in the latter half failed to reproduce the same effect. On the other hand, EGF exhibited a similar stimulatory effect if added to the medium at and after $48 \mathrm{~h}$ of incubation. EGF added in the first $48 \mathrm{~h}$ could not induce these effects. Nulsen et al. [23] reported a similar stimulatory effect of EGF $(10 \mathrm{ng} / \mathrm{m} l)$ on hCG secretion but it was after a much longer incubation time than $96 \mathrm{~h}$.

The present study, which used $10 \mathrm{ng} / \mathrm{m} l \mathrm{EGF}$ over 4 days of culture, could not confirm the conclusion of Morrish et al. [18] who observed morphological differentiation of C-cells to S-cells induced by $100 \mathrm{ng} / \mathrm{ml}$ EGF. They used mononuclear cells which had been precultured in FCS-free medium for 6 days or more. It is possible that this difference in findings may be explained by the fact that the mononucleated cells in the study of Morrish et al. [18] had already differentiated into intermediate trophoblastic cells or had acquired the functional character of S-cells by the time EGF was added to the medium on the 6th day of preculture. This possibility may be entertained because since day 1 of preculture the mononucleated cells had been secreting hPL, thereby exhibiting one characteristic of intermediate trophoblastic cells even before exposure to EGF. Moreover, if the increased secretion of hCG and hPL by the precultured cells was interpreted as induced by EGF, then such an interpretation assumes that the precultured cells have a sufficient amount of EGF receptors. However, in term placentas, the notable presence of EGF receptors is a characteristic of S-cells and not of C-cells [24]. Therefore, while EGF stimulated hCG and hPL secretion in the study of Morrish et al. [18], this effect might be unrelated to the ability or inability of EGF to induce morphological changes in cultured mononucleated cells. DePalo and Das [21] have demonstrated that EGF stimulates EGF-receptor biosynthesis in cultured C-cells. This, however, would explain the ability of their precultured cells to react with EGF. They observed the EGF effect in C-cells cultured in $20 \%$ FCS medium, while Morrish et al. maintained an FCS-free medium. Furthermore, Morrish et al. [18] exposed the culture to $100 \mathrm{ng} / \mathrm{ml}(\fallingdotseq 17 \mathrm{nM})$ of EGF, a concentration which DePalo and Das [21] found stimulate the degeneration, not the production, of EGF receptors in cultured C-cells. In such an environment, it would be difficult to understand how, as reported by DePalo and Das, EGF could induce EGF receptor biosynthesis in cultured C-cells. This area, therefore, requires further examination.

At any rate, because the increased expression of hCG and hCG- $\alpha$ induced by $\mathrm{T}_{3}$ and EGF was not accompanied by morphological changes, the present study suggests that the target cell of $\mathrm{T}_{3}$ is the C-cell, while the S-cell is the target of EGF. Our findings also suggest that in term placenta, the interaction between $T_{3}$ and its receptor facilitates functional cell differentiation without C-cell proliferation. At term, the S-cells are terminally differentiated and no longer have the capacity to divide [25]. It should be further clarified whether thyroid hormone increases EGF receptor and EGF receptor mRNA levels in trophoblast, as mentioned concerning liver [26, 27]. EGF has also been shown to decrease nuclear $\mathrm{T}_{3}$ binding in pituitary $\mathrm{GH}_{4}$ cells in culture [28]. Further investigation of hormone modulation of $\mathrm{T}_{3}, \mathrm{EGF}$ and their receptors should be of great interest.

Although the present immunocytochemical results cannot be ascribed to a lack of EGF receptors on the initial C-cells, our data may support a part of a similar thesis, proposed by Yamamoto et al. [29]: a paracrine or autocrine control mechanism in which EGF synthesized by C-cells facilitates certain functions, including the induction of EGFreceptor action, of neighboring $\mathrm{S}$-cells or S-cell differentiated from the C-cells themselves. It follows that further studies clarifying EGF synthesis in the C-cell should be undertaken. 


\section{Acknowledgments}

This work was supported in part by Grants-in-
Aid for General Scientific Research C62570758, B63480368 and 03670786 from the Ministry of Education, Science and Culture, Japan.

\section{References}

1. Boyd JD, Hamilton WJ (1970) Trophoblast. In: The Human Placenta. W. Heffer \& Sons, Cambridge, $140-174$.

2. Kliman HJ, Nestler JE, Sermasi E, Sanger JM, Strauss JF III (1986) Purification, characterization and in vitro differentiation of cytotrophoblasts from human term placentae. Endocrinology 118: 1567-1582.

3. Yoshida Y (1964) Ultrastructure and secretory function of the syncytial trophoblast of human placenta in early pregnancy. Exp Cell Res 34: 305-317.

4. Boime I, McWilliams D, Szczesna E, Camel M (1976) Synthesis of human placental lactogen messenger RNA as a function of gestation. $J$ Biol Chem 251: 820-825.

5. Marrs RP, Mishell DR (1980) Placental trophic hormones. Clin Obstet Gynecol 23: 721-735.

6. Midgley AR, Pierce GB (1962) Immunohistochemical localization of human chorionic gonadotropin. J Exp Med 115: 289-294.

7. Lai WH, Guyda HJ, Bergeron JJM (1986) Binding and internalization of epidermal growth factor in human term placental cells in culture. Endocrinology 118: 413-423.

8. Benveniste R, Speeg Jr KV, Carpenter G, Cohen S, Lindner J, Rabinowitz D (1978) Epidermal growth factor stimulates secretion of human chorionic gonadotropin by cultured human choriocarcinoma cells. J Clin Endocrinol Metab 46: 169-172.

9. Ashitaka Y, Nishimura R, Takemori M, Tojo S (1980) Production and secretion of HCG and HCG subunits by trophoblastic tissue. In: Segal SJ (ed) Chorionic Gonadotropin. Plenum Publ, New York, 145-175.

10. Lai WH, Guyda HJ, Branchaud CL, Goodyer CG (1981) Insulin-induced receptor regulation in early gestation and term human placental cell culture. Placenta 6: 505-517.

11. Chaernausek SD, Jacobs S, Van Wijk JJ (1981) Structural similarities between human receptors for somatomedin $\mathrm{C}$ and insulin: analysis by affinity labeling. Biochemistry 20: 7345-7350.

12. Massague JB, Guillete J, Czech MP (1981) Affinity labeling of multiplication stimulating activity receptors in membranes from rat and human tissues. $J$ Biol Chem 256: 2122-2125.

13. Takano K, Hall K, Fryklund L, Holmgren A, Sievertsson H, Uthne K (1975) The binding of insulin and somatomedin $\mathrm{A}$ to human placental membrane. Acta Endocrinol (Copenhagen). 80: 14-31.

14. Van Buul-Offer S, Van den Brande JL (1979) Binding of somatomedin A and C, NSILA-S and insulin to human placental cell membrane. Horm Res 11: 186-202.

15. Ashitaka Y, Maruo M, Takeuchi Y, Nakayama H, Mochizuki M (1988) 3, 5, 3'-triiodo-L-thyronine binding sites in nuclei of human trophoblastic cells. Endocrinol Japon 35: 197-206.

16. Nishii H, Ashitaka Y, Maruo M, Mochizuki M (1989) Studies on the 3, 5, 3'-L-thyronine binding sites in cultured cytotrophoblast. Endocrinol Japon 36: 891-898.

17. Maruo T, Matsuo H, Oishi T, Hayashi M, Nishino R, Mochizuki M (1987) Induction of differentiated trophoblast function by epidermal growth factor; relation of immunohistochemically detected cellular epidermal growth factor receptor levels. J Clin Endocrinol Metab 64: 744-750.

18. Morrish DW, Bhardwaj D, Dabbagh LK, Marusyk H, Siy O (1987) Epidermal growth factor induces differentiation and secretion of human chorionic gonadotropin and placental lactogen in normal human placenta. J Clin Endocrinol Metab 65: 1282-1290.

19. Hock RA, Hollenberg MD (1980) Characterization of the receptor for epidermal growth factor urogastrine in human placental membranes. I Biol Chem 255: 10731-10736.

20. Ashitaka Y, Nishimura R, Endo Y, Tojo S (1974) Subunits of human chorionic gonadotropin and their radioimmunoassays. Endocrinol Japon 21: 429-435.

21. DePalo L, Das M (1988) Epidermal growth factorinduced stimulation of epidermal growth factorreceptor synthesis in human cytotrophoblast and A431 carcinoma cells. Cancer Res 48: 1105-1109.

22. Dreskin RW, Spicer SS, Greene WB (1970) Ultrastructural localization of chorionic gonadotropin in human term placenta. $J$ Histochem Cytochem 18: 862-874.

23. Nulsen JC, Woolkalis MJ, Kopf GS, Straus JF III (1987) Adenylate cyclase in human cytotrophoblasts: characterization and its role in modulating human chorionic gonadotropin secretion. Endocrinology 66: 258-265.

24. Morgan M, Nanney LB, Stoscheck CM, King LE Jr. (1985) Epidermal growth factor binding and receptor distribution in term human placenta. 
Placenta 6: 519-526.

25. Wynn RM (1973) Fine structure of the placenta. In: Greg RO, Astwood EB (eds) Handbook of Physiology. Vol. 2. American Physiology Society, Washington DC, 261-276.

26. Mukku VR (1984) Regulation of epidermal growth factor receptor levels by thyroid hormone. $J$ Biol Chem 259: 6543-6546.

27. Hoath SB, Pickens WL, Bucuvalas JC, Suchy FJ (1987) Characterization of hepatic epidermal growth factor receptors in the developing rat. Biochem Biophys Acta 930: 107-113.

28. Kaji H, Hinkle PM (1987) Epidermal growth factor decreases thyroid hormone receptors and attenuates thyroid hormone response in $\mathrm{GH}_{4} \mathrm{C}_{1}$ cells. Endocrinology 120: 537-543.

29. Yamamoto T, Nishiyama M, Naka A, Nomura $H$, Sugiyama Y (1988) Role of epidermal growth factor in reproduction. Acta Obstet Gynaec Japon 40: 655-660 (In Japanese). 